\title{
History Education: The Case of Estonia
}

\author{
Mare Oja
}

\begin{abstract}
This paper presents an overview of changes in history teaching/learning in the general education system during the transition period from Soviet dictatorship to democracy in the renewed state of Estonia. The main dimensions revealed in this study are conception and content of Estonian history education, curriculum and syllabi development, new understanding of teaching and learning processes, and methods and assessment. Research is based on review of documents and media, content analysis of textbooks and other teaching aids as well as interviews with teachers and experts. The change in the curriculum and methodology of history education had some critical points due to a gap in the content of Soviet era textbooks and new programmes as well as due to a gap between teacher attitudes and levels of knowledge between Russian and Estonian schools. The central task of history education was to formulate the focus and objectives of teaching the subject and balance the historical knowledge, skills, values, and attitudes in the learning process. New values and methodical requirements were included in the general curriculum as well as in the syllabus of history education and in teacher professional development.
\end{abstract}

Keywords: history education, history curriculum, methodology

\section{Introduction}

Changes in history teaching began with the Teachers' Congress in 1987 when Estonia was still under Soviet rule. The movement towards democratic education emphasised national culture and Estonian ethnicity and increased freedom of choice for schools. In history studies, curriculum with alternative content and a special course of Estonian history was developed. In the Soviet school, Estonian history was taught fragmentarily and from an imperial position. Due to rapid political changes, textbooks were largely outdated, and teachers created study materials based mainly on printed media. In history, the 'blank pages', i.e. events and phenomena that were not dealt with in Soviet society or lacked adequate information, were filled. Not everyone was prepared to abandon Soviet-style traditions, fearing Moscow's power or the return of the former regime. ${ }^{1}$

On 20 August 1991, the Supreme Council of the Republic of Estonia passed 'On National Independence of Estonia' restoring the independent state.

\footnotetext{
1 For example, the compiler of the first materials published in 1989, Silvia Õispuu, had difficulty finding historians who would agree to write about the period of the first independence (1918-1940). Silvia Õispuu, interview by Mare Oja, 11 October 2015, Personal archives of Mare Oja.
} 
A democratic understanding of education put student skills development at the centre of teaching/learning and supported diversification of choice. From 1991 to 2004, laws were adopted including the first national curriculum (1996) and the amended and revised version (2002), which set out the demands and content of history studies. Over the years, the content, perceptions of teaching and learning and methodology, assessment, and teacher roles were transformed.

This study presents overview of changes in history teaching/learning in the general education system during transition period from Soviet dictatorship to democracy in Estonia. The main topics are concept and content of Estonian history education, curriculum and syllabi development, new understanding of teaching/learning processes, methods, and assessment.

\section{Updating subject content and syllabus development}

History teaching in the Soviet Union until 1987 was characterised by a more prominent position of the history of Soviet Union compared to national histories. The changes consisted of increasing or decreasing the number of history lessons as well as emphasis on Soviet ideological education (e.g., the appreciation of atheistic education, etc.). Substantive changes in history studies remained minimal. ${ }^{2}$ This was also reflected in the programmes ${ }^{3}$ and methodological aids issued by the Ministry of Education of Soviet Estonia.

The Teachers' Congress in 1987 was followed by brainstorming sessions from which a group of volunteers emerged who began to update the subject content of history. Work began at the Institute for Research in Pedagogy, which coordinated the development of history studies under the guidance of the Ministry of Education at the end of the 1980s and early 1990s. In 1993, curriculum development was moved to the Estonian State Board of Education ${ }^{5}$ and from 1996, after the liquidation of the institution, the Ministry of Education took over.

In October 2000, when the University of Tartu won the competition for the development of national curricula for the Ministry of Education and Research, the Centre for Educational Studies and Curriculum Development

2 A. Raudsepp, 'Ajaloo õpetamise korraldus Eesti NSV eesti õppekeelega üldhariduskoolides 1944-1985' [The organisation of history teaching in Estonian-speaking Schools in Estonian SSR in 1944-1985], PhD diss., University of Tartu, 2005, pp. 66, 67, 74.

3 During the Soviet era, the Ministry of Education issued detailed descriptions of the learning process - programmes for all subjects: how many hours to focus on different topics, most important knowledge, methodological suggestions, etc. Very little freedom for teachers was left.

4 Silvia Õispuu, interview by Mare Oja, 11 October 2015, Personal archives of Mare Oja.

5 'Kultuuri - ja haridusministri määrused. Riigi Kooliameti põhimääruse kinnitamine. RT 1993, 12.0' [Regulations of the Minister of Culture and Education. Approval of the Statutes of the State Board of Education. The Parliament Acts 1993, Act no. 12.0], Ministry of Education and Culture, no. 5, 20 May 1993. Available: https://www.riigiteataja.ee/akt/24461 (accessed 02.05.2020). 
(Curriculum Development Centre) ${ }^{6}$ was established at the University of Tartu and coordinated the development of primary, basic, and secondary education curricula, especially the general introduction of the curriculum. The subject syllabi of the National Curriculum 2002 were still prepared by national subject councils ${ }^{7}$ under the coordination of the Ministry of Education. The subject council played a significant role in decisions on history education. Subject councils assessed textbooks and workbooks and discussed issues of subject matter such as content of student competitions ('Olympiads'), final examinations after graduation from basic school, ${ }^{8}$ national examinations after secondary level, ${ }^{9}$ and recommendations for improving subject teaching. In 2002, an information day was organised for history teachers in vocational education institutions. ${ }^{10}$ In September 2003, general education history teachers were provided with information. ${ }^{11}$ Subject councils were the focal point for delivering educational policy decisions to teachers.

\section{Transition period for new study programs 1988-1992}

The primary aim was to dismantle the unified Soviet syllabus and teach more Estonian history. In 1988, experimental programs were developed to present less-politicised prehistory, ancient, and Middle Ages history. Estonian history was still taught from the point of view of the Soviet Union. General guidelines were still Soviet: bureaucratic vocabulary was still used, referring to quotes by Lenin and decisions made by the $27^{\text {th }}$ Congress of the Communist Party. Simultaneously, it was acknowledged that the past should be discussed publicly and honestly to overcome falsification of history prevalent during the Soviet era. Gorbachev's perestroika and glasnost made public discussion

\footnotetext{
${ }^{6}$ 'Keskusest' [About the Center]. Available: http://www.curriculum.ut.ee/et/keskusest (accessed 23.02.2015).

7 The subject councils were advisory councils of the Ministry of Education, which were already discussing issues of teaching subject matter during the Soviet era. In Estonia in 1996, the Minister of Education decreed formation of subject councils as advisory bodies on subject studies: See 'Üleriigiliste ainenõukogude moodustamine. Ministri käskkiri nr. 51, 12.03 .1996 [Foundation of nationwide subject councils. Decree of the Minister no. 51, 12.03.1996.], Archive of the Ministry of Education and Science, file 2-1-6 (1). Available: https://www.riigiteataja. ee/akt/73189 (accessed 2.05.2020); 'Üleriigiliste ainenõukogude moodustamine, ülesanded ja töökord. Haridus- ja teadusministri käskkiri nr. 367, 26.03.2008. [Foundation, tasks and rules of procedure of nationwide subject councils. Decree of the Minister of Education and Science no. 367, 26.03.2008.], Archive of the Ministry of Education and Science, sari [series] 1.1-2/2008.

${ }_{8}^{8}$ Basic school (grades 1-9, pupils aged 7-15/16) is compulsory education in Estonia.

9 The first national examinations were introduced 1997. Estonian language, mathematics, and one foreign language were compulsory. Examination in history was optional. Universities accepted results of national examinations as entrance exams for university. Optional state exams could be taken until 2013.

10 'Ajaloo ainenõukogu koosoleku protokoll, 20.09.2002 Ainenõukogude protokollid 2001-2003' [The report of the meeting of the Council of History, 20.09.2002. Reports of subject councils 2001-2003], in Riiklik Eksami- ja Kvalifikatsioonikeskus [State Center for Examination and Qualification series], vol. 3-12, 2003.

${ }^{11}$ Ibid.
} 
possible. Humans became the center of history teaching, but the justifying concept was sought in Marxism classics. The need to stimulate the skills of formulating and justifying personal opinion was also highlighted, ${ }^{12}$ unlike Soviet fact-based history teaching. Educational literature was recognised as obsolete. History teachers were asked to follow the press and use the latest viewpoints found in media, published documentary collections, Estonian Radio and Television programmes as well as Soviet press, Mikhail Gorbachev and Alexander Jakovlev's statements, ${ }^{13}$ and articles by outstanding historians. Lenin's books, recommended for discussion of several historical topics, were also considered valuable in teaching. ${ }^{14}$ Although state control began to decline in 1988/89, the 'old' and the 'new' remained side by side for some time in history materials and ways of thinking. This was illustrated by Lenin's statue and the Estonian national flag (banned during the Soviet era) adjacent to the main road. However, abandonment of the old concepts may have been difficult in light of new discoveries in history as one teacher recognised: "I really believed that Lenin was good."

Soviet textbooks were no longer relevant as they had marginalized Estonian history and taught it only from the point of view of the empire, so teachers prepared for lessons by using university materials and lecture notes. One teacher recalled: "I had to start teaching the history of Estonia in secondary school in 1989. I went to Tartu University library to compile a summary based on a university textbook Estonian history volumes I-III, and I also looked for materials about the [first] Republic of Estonia." Teachers explained history to students in a lecture and students took notes. Teachers sought information from several sources so lectures were a legitimate learning/teaching method. Student interest in history was very high during the transition period. They brought grandparents' diaries to school, pre-Soviet history books, and other sources that were studied with the teacher and classmates. ${ }^{16}$

A teacher recalled watching documentaries about Estonian history, which was commented on by historian Lauri Vahtre. ${ }^{17}$ "We went with our students to

${ }^{12}$ Ajalugu IV-XI klassile. Üldhariduskooli programmid [History for 4-9 grades. Syllabi for compulsory school], Tallinn, Eesti NSV Haridusministeerium, 1988, pp. 3-4.

${ }^{13}$ Alexander Nikolaevich Yakovlev was a Soviet politician and historian. During the 1980s, he was a member of the Politburo and Secretariat of the USSR Communist Party. Known as the "godfather of glasnost", he is considered to be the intellectual force behind Mikhail Gorbachev's reform glasnost and perestroika programmes. Yakovlev was the first Soviet politician to acknowledge the existence of the secret protocols of the 1939 Molotov-Ribbentrop Pact between Nazi Germany and the USSR.

${ }^{14}$ J. Nurmik (ed.), Uutest programmidest ja õppemeetodilisest kirjandusest 1988/89. õppeaastal [On new programmes and methodological literature in 1988/89 academic year], Tallinn, Eesti NSV Haridusministeerium, 1988, p. 7.

${ }^{15}$ M. Oja, 'Muutused üldhariduskooli ajalooõpetuses alates 1987.aastast - nõukogulikust tänapäevaseks' [Changes in compulsory school history education since 1987 - from Soviet to present], PhD diss., Tallinn University, 2016, p. 306.

${ }^{16}$ Ibid., pp. 307-308.

${ }^{17}$ Lauri Vahtre is an Estonian politician, historian, writer, screenwriter, translator, and author of several history textbooks. 
Rakvere ... to watch this program; the hall was full of students and teachers. In the early 1990s, there was a television show 'Stories from past times', which contained summaries of Estonian history. We watched those lessons, it was good illustrative material." 18

In 1989, there were two variations of the history curriculum: 1) the AllUnion in which it was recommended to combine Estonian history with the corresponding topics of the history of the Soviet Union and 2) the new projected programme drawn up by the program work groups. ${ }^{19}$ Teachers could choose which of the programmes to work with.

The first new study plan was approved by the Estonian SSR National Education Committee in the spring of 1989 . History was taught from $5^{\text {th }}$ to $9^{\text {th }}$ grade for two lessons per week. In tenth grade, history teaching was divided into compulsory two lessons per week for everyone and an optional additional three lessons per week for humanities-based studies. Sciences-based studies also had only two lessons per week. Grades 11 and 12 had three history classes per week. ${ }^{20}$ In-depth history was an optional elective course.

The topics of the programs were presented class-by-class and lesson-bylesson in the teacher guide, including exercises and examples of integration between different subjects, key concepts, and historical figures and events. Outcomes for the end of each grade were summarised. This detailed description helped teachers plan subject teaching as well the textbook authors to follow the guidelines, but left teachers little opportunity to plan independently.

In 1989/90, Estonian general education schools adopted a new curriculum. ${ }^{21}$ The history syllabus was developed as a linear course of world history with main topics of Estonian history ${ }^{22}$ instead of the former curriculum of USSR and foreign country history. In the $11^{\text {th }}$ grade, a systematic course of Estonian history was added (three classes per week), the most significant update to

${ }^{18}$ M. Oja, 'Muutused üldhariduskooli ajalooõpetuses alates 1987. aastast - nõukogulikust tänapäevaseks' [Changes in compulsory school history education since 1987 - from Soviet to present], PhD diss., Tallinn University, 2016, p. 307.

${ }^{19}$ S. Õispuu (ed.), Täiendused 1988. aastal ilmunud ajalooprogrammide juurde [Supplements on history programmes published in 1988], Tallinn, Eesti NSV Riiklik Hariduskomitee, Tallinn, 1989, p. 3.

20 'Muudatustest haridustöötajate töö normeerimisel ja tasustamisel ning õpilaste materiaalsel kindlustamisel. Eesti NSV Riikliku Hariduskomitee käskkiri nr 118, 14.11.1988.' [Changes in the standardization and remuneration of the work of educators and in the material provision of students. Decree of the ESSR State Committee of Education no. 118, 14.11.1988.], Infobülletään [Info Bulletin], no. 1, 1989.

21 'Üldhariduskooli õppeplaan 1989/90. Õppeaastaks. Eesti NSV Riikliku Hariduskomitee 11. aprilli 1989. a käskkiri nr 177' [Curriculum for compulsory school for 1989/90 academic year. Decree of ESSR State Committee of Education no. 177, 11 April 1989.], Infobülletään [Info Bulletin], no. 1, 1989.

22 J. Nurmik (ed.), 'Programmidest ja õppemetoodilisest kirjandusest 1989/90. Õppeaastal' [On programmes and methodological literature in 1989/90 academic year], EPAM [Archival Museum of Estonian Pedagogics at the University of Tallinn], R29296, p. 35; S Õispuu (ed.), Täiendused 1988. aastal ilmunud ajalooprogrammide juurde [Supplements on history programmes published in 1988], Tallinn, Eesti NSV Riiklik Hariduskomitee, 1989. 
the study plan. The purpose of teaching Estonian history ${ }^{23}$ was to shape learners' understanding of the development of the history of Estonian people in the context of world history.

Russian-language schools continued to follow the Soviet curriculum, the history of the USSR and general history. Estonian history was not systematically addressed: a few topics based on the history of the USSR were taught simultaneously. ${ }^{24}$ The concept and syllabi of history teaching adopted in 1989/90 were translated into Russian, and teachers were invited to implement it, ${ }^{25}$ but there were no direct requirements to do so. Emphasis was place on the fact that everyone living in Estonia should, in addition to general history, know the history of the local people. Teaching of Estonia history was recommended for 35 lessons in $9^{\text {th }}$ grade and 35 lessons in $10^{\text {th }}$ grade. Estonian history was assessed with a special mark on the secondary school graduation certificate, ${ }^{26}$ so it could not be ignored. Changes in 1989/90 included an increase in the number of lessons in for Estonian language learning in non-Estonian language schools. In 1990/91, 'Estonica' - Estonian history, culture, language, geography, and nature - began to be taught. In 1992/93, civic education was introduced. ${ }^{27}$

The mentality that dominated in Russian-language schools was generally empire-centric, based on the collective memory of the Soviet era that refused to acknowledge different interpretations of history. Russian-language school teachers' knowledge of Estonian history was virtually non-existent since they were educated in the universities of Soviet Russia (mainly St. Petersburg and Pskov Pedagogical Institute) where Estonian history was not taught. Those who did not know the Estonian language (the poor level of Estonian language skills in teachers in schools with Russian as the langue of instruction is still a problem) could not use literature and the press. Russian-language press remained Soviet-ideology oriented.

Russian-language school teachers were concerned about the decline in content of Russian and Soviet history in books and classes. ${ }^{28}$ They relied on Russian instructions rather than searching for their own methods to teach Russian. They hoped a working group would be set up by Estonian and Russian

${ }^{23}$ S. Õispuu (ed.), Täiendused 1988. aastal ilmunud ajalooprogrammide juurde [Supplements on history programmes published in 1988], Tallinn, Eesti NSV Riiklik Hariduskomitee, 1989, p. 27.

${ }^{24}$ S. Õispuu (ed.), Üldhariduskooli programmid. Ajalugu V-XII klassile [Programmes for compulsory school. History $5^{\text {th }}-12^{\text {th }}$ grades], Tallinn, 1990, p. 10.

${ }^{25}$ Programmy obchceobrazovatelnyh shkol. Istoria. Project [Programmes for compulsory school. History. Project/Draft], Tallinn, 1990, pp. 3-56.

${ }^{26}$ Istoria Estonii, grazhdanovedenie, chelovek $i$ obchcestvo. Programma dlya obchcobrazovatelnyh shkol s russkim yazykom obucheniya, proftehuchilictch i tehnikumov [History, civics, person and society. Programmes for compulsory schools, vocational and technical schools working in Russian language], Tallinn, 1990, p. 3.

${ }^{27}$ N. Lapikova, 'Venekeelsest haridusest Eestis' [On education in the Russian-language in Estonia], Haridus [Education], no. 2, 1998, pp. 9-10.

${ }^{28}$ Ü. Tikk, 'Ajaloo õpetamisest riigieksami künnisel' [Teaching history at the dawn of state exam], Õpetajate Leht [Teachers' Newspaper], 15 May 1998. 
historians who would debate the events of the $20^{\text {th }}$ century in particular and write a common history textbook. ${ }^{29}$

Conflict in historical memory of Soviet-era knowledge had to be reassessed. One teacher recalled: "And then there were a lot of people who remembered how it really was, but we taught the way the state needed it. Of course, I spoke about how in the village in 1948 people went to a collective farm, they joined themselves, and how bad the kulaks were and that it was the right decision to send them off ... One parent ... asked [the teacher] after a lesson - do you really know what you are talking about? I began to suspect - the book is not the source of the truth..." Many teachers recognised that they believed the official history, or at least were under its influence, but now current knowledge was reversed. For some, the reappraisal of history was a shock, and there where cases when reverted ideas were not believed. Some teachers were not ashamed of their lack of knowledge: "So I learned with the students, no shame."30

The goals of history studies were formulated in the curriculum through knowledge, skills, and attitudes. ${ }^{31}$ The goal was to move from the fact teaching to application of knowledge - to be able to make a personal judgment and to justify it and to be ready for independent assessment. Many of the principles formulated remain relevant and are included in the current state curriculum.

In 1991/92, transition to the new curriculum was completed and the underlying concept of history education was an improved and revised version of the previous concept. ${ }^{32}$ Periods of history taught in different grades remained unchanged. An introductory course was added to the $5^{\text {th }}$ grade for 70 classes per year. ${ }^{33}$ There were three different program versions proposed for $5^{\text {th }}$ grade from which the teacher could choose. Two versions were based on world history, and the third focused on Estonian history. ${ }^{34}$ In the $6^{\text {th }}$ grade, students learned about ancient history, ${ }^{35}$ and the $7^{\text {th }}$ grade learned about the Middle Ages. ${ }^{36}$ In $8^{\text {th }}$ grade, pupils learned the history of late medieval period up to

29 Ü. Tikk, 'Ajaloo õpetamisest riigieksami künnisel' [Teaching history at the dawn of state exam], Oppetajate Leht [Teachers' Newspaper], 15 May 1998.

${ }^{30}$ M. Oja, 'Muutused üldhariduskooli ajalooõpetuses alates 1987. aastast - nõukogulikust tänapäevaseks' [Changes in compulsory school history education since 1987 - from Soviet to present], PhD diss., Tallinn University, 2016, p. 312.

31 J. Nurmik (ed.), 'Programmidest ja õppemetoodilisest kirjandusest 1989/90. Õppeaastal' [On programmes and methodological literature in 1989/90 academic year], EPAM [Archival Museum of Estonian Pedagogics at the University of Tallinn], R29296, p. 34; S. Õispuu (ed.), Täiendused 1988. aastal ilmunud ajalooprogrammide juurde [Supplements on history programmes published in 1988], Tallinn, Eesti NSV Riiklik Hariduskomitee, 1989, pp. 4-5; S. Õispuu (ed.), Üldhariduskooli programmid. Ajalugu V-XII klassile [Programmes for compulsory school. History $5^{\text {th }}-12^{\text {th }}$ grades], Tallinn, 1990 , pp. 8-9.

32 S. Õispuu (ed.), Üldhariduskooli programmid. Ajalugu V-XII klass [Programmes for compulsory school. History in $5^{\text {th }}-12^{\text {th }}$ grade], Tallinn, 1992, p. 2.

33 Ibid., p. 11.

34 Ibid., p. 19.

35 Ibid., pp. 40-44.

36 Ibid., pp. 44-49. 
modern history. ${ }^{37}$ The $9^{\text {th }}$ grade studied the French Revolution and the period to the end of the $19^{\text {th }}$ century. ${ }^{38}$ In $10^{\text {th }}$ grade, the period from the beginning of the $20^{\text {th }}$ century until 1938 was taught. ${ }^{39}$ In grade 11, the history of Estonia from the ancient times until 1991 was to be taught. A separate topic was emigration and life in exile. ${ }^{40}$ Integration of Estonian history into large-scale blocks as part of global history was considered. ${ }^{41}$ The $12^{\text {th }}$ grade covered the period from the Second World War to the last quarter of the $20^{\text {th }}$ century. ${ }^{42}$

The concept of history education focused on the question of why we need to learn history. The answer was the need to highlight identity formation, explain the present and possibilities of the future, develop thinking and communication skills, ${ }^{43}$ present various interpretations of historical events, develop critical thinking skills, and, in particular, deepen the interest in history ${ }^{44}$ Teachers received explanations that instead of fixed assets (key facts), learning outcomes should look at the overall picture of the main stages of world history and develop the ability to discuss differing opinions and not just compile a list of events, dates, and names. ${ }^{45}$ Teachers were encouraged to develop goals and themes based on general objectives. ${ }^{46}$ Key concepts - democracy, imperialism, and human rights - were at the centre of history teaching/learning. Learning outcomes required an understanding of history, including knowledge of facts to support an opinion. It was suggested that studies should be associated with students' personal life experiences, familiar places, creative tasks, class trips and museum studies, making a family tree, writing memoirs, and discussing historical books and films. It was emphasised that the teacher should give fewer lectures and encourage students to express their own opinions. ${ }^{47}$ The problem with renewal of the syllabus was that the periodisation used in teaching was still Soviet and also the fact that there was no justification for the choice of facts taught in history lessons. The process of renewal of history education indicated that we were still at the very beginning of a long and difficult road.

\footnotetext{
${ }^{37}$ S. Õispuu (ed.), Üldhariduskooli programmid. Ajalugu V-XII klass [Programmes for compulsory school. History in $5^{\text {th }}-12^{\text {th }}$ grade], Tallinn, 1992, pp. 50-55.

${ }^{38}$ Ibid., pp. 55-62.

${ }^{39}$ Ibid., pp. 62-66.

${ }^{40}$ Ibid., pp. 66-75.

${ }^{41}$ S. Õispuu (ed.), Üldhariduskooli programmid. Ajalugu V-XII klassile [Programmes for compulsory school. History in $5^{\text {th }}-12^{\text {th }}$ grade], Tallinn, 1990, pp. 96-97.

${ }^{42}$ S. Õispuu (ed.), Üldhariduskooli programmid. Ajalugu V-XII klass [Programmes for compulsory school. History in $5^{\text {th }}-12^{\text {th }}$ grade], Tallinn, 1992, pp. 75-80.

${ }^{43}$ Ibid., p. 5.

${ }^{44}$ Ibid., pp. 6-7.

${ }^{45}$ Õppeprogrammidest ja óppe-metoodilisest kirjandusest 1992/93. õ-a [On programmes and methodological literature in 1992/93], Tallinn, 1992, p. 56.

${ }^{46}$ Ibid., p. 57.

${ }^{47}$ S. Õispuu (ed.), Üldhariduskooli programmid. Ajalugu V-XII klass [Programmes for compulsory school. History in $5^{\text {th }}-12^{\text {th }}$ grade],Tallinn, 1992, pp. 19-22.
} 
To be aware of the wider picture of history studies, teachers and programme developers studied the experience of other countries. ${ }^{48}$ They discovered that a functioning structure and methodology could not be taken directly from elsewhere. Analysis revealed that history was being taught insufficiently and knowledge was poor. Estonia's advantage in the late 1980s and early 1990s was society's great interest in history. ${ }^{49}$ The Swedish model appeared to embrace the concept of concentric teaching and higher generalisation levels, rather than continuing factual instruction about individual countries. For a society with a Soviet past in which the collective and not the individual was important, the issue of identity was essential, without becoming nationalistic: ${ }^{50}$ studies should be centred on Estonian history, but the history of national minorities living in the country should also be considered. ${ }^{51}$

Personal experiences were also used in the development of the history curriculum. Silvia Õispuu, who was responsible of curriculum development in history at the Institute of Scientific Research of Pedagogy, recalled that she witnessed Western history lessons for the first time in Canada in 1989 while visiting relatives. Relatives and friends sent her textbooks and study programmes from Australia. Horizons opened through interaction with the International Society for History Didactics in 1991 and studies at the Danish Royal College as part of teacher in-service training, which introduced different programmes, literature, school culture, and study environments. ${ }^{52}$ Thus, when designing innovations, foreign experience was assessed based on suitability for Estonian schools.

Development of the first history syllabi was a collective effort. ${ }^{53}$ Transition to new study programmes that began in 1989 marked the dissolution of the Soviet

48 'Tallinna Pedagoogilise Instituudi Pedagoogikauuringute Instituut. Ajaloo- ja kodanikuõpetuse kontseptsiooni lähtekohad. 1991. aasta teadusaruanne' [Pedagogical Research Institute of Tallinn Pedagogical Institute. Origins of the concept of history and civics. Scientific report of 1991], manuscript, EPAM [Tallinn University Estonian Pedagogical Archives and Museum], K44268, pp. 1-3.

${ }^{49}$ H. Piirimäe. 'Ajalooõpetus ja ühiskond I. Diskussioone ja arutlusi (eriti Põhjamaades)' [History teaching and Society I. Debates and discussions (especially in the Nordic countries)], Haridus [Education], no. 2, 1992, p. 6; H. Piirimäe, 'Ajalooõpetus ja ühiskond II. Diskussioone ja arutlusi (eriti Põhjamaades) [History teaching and Society II. Debates and discussions (especially in the Nordic countries)], Haridus [Education], no. 3, 1992, pp. 10, 13.

50 'Tallinna Pedagoogilise Instituudi Pedagoogikauuringute Instituut. Ajaloo- ja kodanikuõpetuse kontseptsiooni lähtekohad. 1991. aasta teadusaruanne [Pedagogical Research Institute of Tallinn Pedagogical Institute. Origins of the concept of history and civics. 1991, scientific report], manuscript, EPAM [Archival Museum of Estonian Pedagogics at the University of Tallinn], K44268, pp. 44-49, 81-97.

${ }^{51}$ S. Õispuu. 'Veel ajalooõpetuse kontseptsioonist' [More about the history teaching concept], Haridus [Education], no. 4, 1992, pp. 14-17.

52 Silvia Õispuu, interview by Mare Oja, 11 October 2015, Personal archives of Mare Oja.

53 'Tallinna Pedagoogilise Instituudi Pedagoogikauuringute Instituut. Ajaloo - ja kodanikuõpetuse kontseptsiooni lähtekohad. 1991. aasta teadusaruanne' [Pedagogical Research Institute of Tallinn Pedagogical Institute. Origins of the concept of history and civics. Scientific report, 1991], manuscript, EPAM [Archival Museum of Estonian Pedagogics at the University of Tallinn], K44268, pp. 5-6; S. Õispuu (ed.), Üldhariduskooli programmid. Ajalugu V-XII klass [Programmes for compulsory school. History in $5^{\text {th }}-12^{\text {th }}$ grade], Tallinn, 1990, p. 3 . 
era and attempts to overcome the Soviet "approach." By 1992, a new program had been implemented in all grades. The history of Estonia took a leading position, reversing the position of the history of the Soviet Union. Attention was focused on political history, although cultural history was also studied. The main concept and principles clearly stated that understanding cause and consequences, development of the "big picture," and learning acquisition of skills was more important. However, the subject syllabus continued to be a rather detailed description of study topics, as it was in the Soviet era. This was needed at that time because teachers worked without books and other teaching aids. However, these changes covered only schools with Estonian as the language of instruction. Russian-language schools continued to teach history teaching/ learning on the basis of Soviet textbooks. The Estonian education system was finally united with its first national curriculum in 1996.

\section{National curriculums of 1996 and 2002}

The first national curriculum was adopted in September $1996 .^{54}$ The curriculum was prepared by working groups at the State Education Board's General Education Department. Both academic historians and history teachers took part in history curriculum design. This ended the great freedom of the transition period, which a number of teachers appreciated, but others considered disorder. According the national curriculum, teachers had to achieve the learning outcomes set out in the curriculum, but they had the freedom to decide which topics to study in depth and in which topics to overview in general. A solid step towards harmonizing history studies was taken, but changing teaching practice was a long-term process.

Three years of work preceded the adoption of the curriculum. Fundamental principles were developed by researchers of the Institute of Scientific Research in Pedagogy: general principles in 1986 and development of the history curriculum in 1991, approved by the Ministry of Culture and Education in January 1994. Based on this, a working version of the curriculum was prepared and published in six booklets. Discussion of the working version resulted in a curriculum option, a project that was published in 1995 for feedback from schools. ${ }^{55}$

The structure of the history syllabus was concentric. This meant that elementary school pupils studied the history of the world, especially Europe and Estonia, from ancient history to the present day; in secondary schools

\footnotetext{
54 'Eesti põhi- ja keskhariduse riikliku õppekava kinnitamine. Eesti põhi- ja keskhariduse riiklik õppekava. Vabariigi Valitsuse määrus nr. 228, 06.09.1996.' [Approval of the national curriculum for basic and secondary education in Estonia. National Curriculum for Basic and Secondary Education in Estonia. Regulation of Government of the Republic Regulation no. 228, 06.09.1996.], RT I, 1996, 65 [The Parliament Acts I, 1996, no. 65], p. 1201. Available: https:// www.riigiteataja.ee/akt/162998 (accessed 02.05.2020).

55 Pöördumine lugeja poole. Põhikooli ja gümnaasiumi õppekava. Projekt [Refer to the reader. Basic and high school curriculum. The project/draft], Tallinn, 1995.
} 
there was a second round of history studies, but with a different emphasis. An independent Estonian history course included the history of the Baltic Sea countries from ancient times to the end of the $19^{\text {th }}$ century. Estonian $20^{\text {th }}$ century history was part of the modern history course. World history from ancient times to the beginning of the $20^{\text {th }}$ century was built on individuals, society, and culture. The concept was developed by University of Tartu professor Helmut Piirimäe, who had already proposed the idea of a world history course in 1992 that would consist of cultural history, including the history of ideas and daily life, describing how people lived, dressed, and behaved.

Chronological events and political, economic, social, cultural ideas were presented in history education, none of which were given preferential treatment. One of the main requirements of the curriculum, pupil development, was followed by problem-oriented teaching in which pupils should draw conclusions on the basis of sources ${ }^{56}$ and express and justify their opinions. In order to shape the concept of historical time, it was suggested that chronological events be introduced thematically by giving characteristic examples from various regions of the world. ${ }^{57}$ Focusing on development of skills took time; therefore, it was not possible to cover all the topics in depth. The use of exemplars was first introduced in 1990/1991.

The task of history teaching was to develop the understanding that without knowledge of the past, it is difficult to understand the course of modern events as well as many issues in Estonian history. The purpose of working with historical sources was to learn about cause and effect, notice similarities and differences, and recognise change and continuity. The development of empathy, the ability to see the world from a different point of view, was important as was being able to introduce various concepts of history without imposition of personal views. In order to understand that the writing of history depended on context and historians' interpretations of sources, comparison of the interpretation of historical events and phenomena was suggested for textbooks and other publications. It was hoped that learning history would help shape the learner's understanding of past experiences. ${ }^{58}$ The principles, including the requirement for multiple perspectives in history studies, clearly indicated that history education did not seek to formulate a firm, official national position, but develop critical thinking skills in the learner.

The primary goals in basic education history studies ${ }^{59}$ were to give the pupil the opportunity to become interested in history. The key objectives were "to learn, to interpret, to understand". The word 'understand' has been used as a requirement for the relationship between causation and contemporary

\footnotetext{
56 'Eesti põhi- ja keskhariduse riiklik õppekava' [National Curriculum for Basic and Secondary Education in Estonia], RT I 27.09.1996, no. 6-69, 1960 [The Parliament Acts I, no. 6-69, 1960, 27.09.1996], p. 2087. Available: https://www.riigiteataja.ee/akt/162998 (accessed 02.05.2020).

${ }^{57}$ Ibid., p. 2088.

${ }^{58}$ Ibid.

${ }^{59}$ Ibid.
} 
events. Goals for gymnasiums ${ }^{60}$ were more ambitious: pupils should be able to interpret, analyse, find evidence, and understand problems. Basic school learning outcomes presupposed that students "knew the major periods of world history and the developmental stages of Estonian society, worked with maps and historical sources, elaborated in brief essays, analysed causal relationships, and justified their positions." ${ }^{61}$ The syllabus did not describe how to evaluate learning outcomes or which criteria to use. The study-process section included descriptions of appropriate teaching methods. Assessment guidelines highlighted objectives to be addressed, examples of forms of control, and explanations of how to support learning through evaluation of the development of the learner's self-esteem. Assessment was to be based on learning outcomes.

The history syllabus of the 1996 National Curriculum summarised the development of history teaching to date. The changes were significant compared to Soviet teaching traditions - the open curriculum was implemented. Many teachers were not ready for a learner-centred approach and making decisions on which topics to study in depth. Some support was provided at meetings where teachers were guided on how to interpret the syllabus. A teachers' guidebook was also published, which included methodological advice and examples on how to follow the syllabus. ${ }^{62}$ Freedom in teaching history during the transitional period was used in various ways by teachers. Some teachers created their own teaching material and enjoyed the freedom to focus on topics that were of interest to them. After adoption of the national curriculum, they had to follow the guidelines and were rather disturbed by this. Most people, however, were delighted that the frame of history teaching was restored. ${ }^{63}$

The 2002 national curriculum was implemented on 1 September. ${ }^{64}$ The 1996 Curriculum was supplemented with changes based on feedback from teachers. The work group, subject council, and groups of experts prepared an updated version of the history syllabus, which was not substantial: they included changes and improvements that were proved necessary on the basis of three years of teaching experience.

${ }^{60}$ Eesti põhi- ja keskhariduse riiklik õppekava' [National Curriculum for Basic and Secondary Education in Estonia], RT I 27.09.1996, no. 6-69, 1960 [The Parliament Acts I, no. 6-69, 1960, 27.09.1996], p. 2091.

${ }^{61}$ Ibid.

${ }^{62}$ Ajaloo aineraamat [History guidebook], Tallinn, 1997; M. Oja, 'Muutused üldhariduskooli ajalooõpetuses alates 1987. aastast - nõukogulikust tänapäevaseks' [Changes in compulsory school history education since 1987 - from Soviet to present], PhD diss., Tallinn University, 2016, p. 208.

${ }^{63}$ M. Oja, 'Muutused üldhariduskooli ajalooõpetuses alates 1987. aastast - nõukogulikust tänapäevaseks' [Changes in compulsory school history education since 1987 - from Soviet to present], PhD diss., Tallinn University, 2016, p. 320.

64 'Põhikooli ja gümnaasiumi riiklik õppekava. Vabariigi Valituse määrus nr. 56' [National Curriculum for basic and high school. Government of the Republic Regulation no. 56], RT I, no. 20, 25.01.2002 [The Parliament Acts I, no. 20, 01.09.2002], p. 116. Available: https://www. riigiteataja.ee/akt/174787 (accessed 02.05.2020). 
There were no major changes in the 2002 Curriculum. The number of classes in elementary school level subjects remained the same. The 1996 Curriculum allowed schools to decide how many lessons per week a particular subject was taught, e.g. in $5^{\text {th }}$ grade, history could be taught 1-2 times a week. The 2002 Curriculum fixed the number of lessons in each grade. ${ }^{65}$ The 1996 secondary school curriculum included eight compulsory courses, but the 2002 Curriculum had seven courses. ${ }^{66}$ Teachers could decide in which order they taught courses. ${ }^{67}$ This led to the need to reduce the amount of mandatory topics. For example, Estonian history gave up the history of Baltic Sea countries and focused solely on Estonian history. Modern history decreased from three to two courses. This change allowed gymnasium-level grades to decide which subjects or courses to add to the school curriculum. The total number of compulsory courses in gymnasium did not change. Thus, schools could also decide to teach more than the seven compulsory courses of history.

Assessment guidance was added to the syllabus. It assumed that "methods to control learning outcomes were varied, including verbal and written interviews; work with maps, source material, and pictures; long-term projects; research papers; and writing essays. Additionally, skills development was also assessed." 68 In project and independent research evaluation, it was considered important to monitor the process, not just the final result. Aspects of evaluation of discussion were described. In total, "the summary grade should be formed from the assessment of various skills" (self-expression and analysis, reproduction of material, essay writing, work with source material, etc.). ${ }^{69}$ Such a requirement emphasised the design of skills in learning.

In the $5^{\text {th }}$ grade, it was advised to understand that "history is really about everyone's story" or one's own biography..$^{70}$ The main aim was to develop interest towards history. In $6^{\text {th }}$ grade, suggested teaching methods included asking questions, planning, storytelling, problem-solving, and simple analysis. ${ }^{71}$ In grades 7 through 9, class trips to museums or archives to encourage student research interests were encouraged..$^{72}$ At the gymnasium level, concentration on the creation of connections and conclusions, formation and justification personal opinions and attitudes, and seeking and critical assessment of information was recommended..$^{73}$

In comparison to the 1996 curriculum, the 2002 version aggregated and generalised learning outcomes, reducing the demand for learning outcomes

\footnotetext{
${ }^{65}$ Põhikooli ja gümnaasiumi riiklik õppekava. Vabariigi Valituse määrus nr. 56’ [National Curriculum for basic and high school. Government of the Republic Regulation no. 56], RT I, no. 20, 25.01.2002 [The Parliament Acts I, no. 20, 01.09.2002], p. 878.

${ }^{66}$ Ibid., p. 881.

${ }^{67}$ Ibid., p. 1016.

${ }^{68}$ Ibid., pp. 1011-1012.

${ }^{69}$ Ibid.

${ }^{70}$ Ibid., p. 1012.

${ }^{71}$ Ibid., p. 1013.

72 Ibid., p. 1014.

${ }^{73}$ Ibid., p. 1017.
} 
at the basic school level. The 2002 Curriculum added secondary school study objectives: pupils should "learn to participate in discussion, argue in a reasoned way, and use and analyse various sources purposefully and critically." ${ }^{34}$

In conclusion, the changes in the 2002 Curriculum were neither fundamental nor great. History teachers liked stability. Teachers were encouraged to follow the changed curriculum by using a methodological study guide. ${ }^{75}$

Coordination between the Center for Educational Studies and the University of Tartu Curriculum Development ${ }^{76}$ from 2000 to 2005 in the subject group 'Human and Society' sought to find the significance of history as a subject in the overall field of general education. More attention was turned to the development of student skills and creation of connections between topics. The main goal of history teaching was to develop critical thinking skills in learners. ${ }^{77}$

\section{Forms of education and methodology in history studies}

Changes in teaching practice occurred more slowly than changes in curriculum. Soviet history teaching was knowledge-centred and laden with ideology, but even then, progressive teachers tried to support development of understanding of history, in particular through research of pupils' neighborhoods that began in the latter half of the 1950s. In the 1980s, the movement involved half of the schools in Estonia. At the end of the 1980s, the Heritage Society initiated a research movement to gathered memories on forbidden topics in Estonian history. This kind of research enabled students to recognise the nature and traditions of their ancestors through time. This would make them think about the kind of traces they would like to leave behind. The tradition of student research continued with the international history research competition, which continues to this day. ${ }^{78}$ Since 2001, the contest is part of the EUSTORY informal network for the study of European students' historical research in which 24 European countries participate. The aim of the competition is to deepen young people's historical interest and develop their independent research skills.

${ }^{74}$ Põhikooli ja gümnaasiumi riiklik õppekava. Vabariigi Valituse määrus nr. 56' [National Curriculum for basic and high school. Government of the Republic Regulation no. 56], RT I, no. 20, 25.01.2002 [The Parliament Acts I, no. 20, 01.09.2002], p. 1016.

${ }^{75} \mathrm{M}$. Oja, 'Ajalugu uuendatud õppekavas' [History in the updated curriculum], in Ajaloo oppetamisest. Abiks õpetajale [Teaching history. Support for the teacher], Tallinn, 2002, pp. 5-22.

${ }^{76}$ About the Centre, see: 'Center for Educational Studies.' Available: http://www.curriculum.ut.ee/ et/keskusest (accessed 23.02.2015).

${ }^{77}$ K. Kello, Ü. Luisk, 'Vähe levinud vaateviisist ajalooõpetusele - riikliku õppekava perspektiivist' [A less common view of history studies - from a national curriculum perspective], Õpetajate Lehe lisaleht [Teachers' Newspaper's Appendix], 18 February 2005, p. 4.

78 T. Ojala, V. Rohtla, '14 aastat õpilaste ajalooalaste uurimistööde võistlusi' [14 years student historical research competitions], in Kakskümmend aastat Eesti Ajaloo- ja Ühiskonnaõpetajate Seltsi [Twenty years of the Estonian Society of History and Civic teachers], Tallinn, 2014, p. 9. 
Students compete with the research completed during the year. ${ }^{79}$ The tradition of the contest strongly supports the principles of the curriculum, and Estonian students have participated in the competition since 1999.

Through the History Olympiad, students were motivated to study history and read history books. The development of subject Olympiads was influenced by general changes in education in the context of political transitions. The 1990 Olympiad was postponed, and the 1991 Olympiad differed from previous competitions. The topic was 'Republic of Estonia, 1918-1940.80 The competition was in three parts: students' own creations, library work on literature about a specific topic, and testing foreign language skills. ${ }^{81}$ The goal was not to compete but rather to offer opportunities for action and self-expression. ${ }^{82}$ However, it returned to the former Olympiad format in which student knowledge was mainly tested, because no better solution was found. Organization of the Olympiad showed what was valued and considered important. In 2000, the obligation to organise the Olympiad transferred to the Estonian History Teachers' Society under an agreement with the Ministry of Education. ${ }^{83}$

Schools have often called on experts to share their knowledge. In schools, archaeology, ethnography, Estonian cultural history, archival studies, history of the Nordics and Baltic German, and other in-depth topics were taught as optional courses. In 1987, when intensive teaching of Estonian history began at Tallinn Secondary School No. 32 in a special class, cooperation with researchers from the Institute of History, the Estonian History Museum, the Estonian State Archives, and the Tallinn City Archives began, and special courses for schools were developed. Students in specialised history-classes had more solid views, compared to their peers, about the global processes taking place in society, politics, and economics. ${ }^{84}$

Class trips were also evaluated as methods for better understanding the past. Students researched local history and created presentations, which they also presented outside the classroom. The most famous were trips were to museums and archives.

79 T. Ojala, V. Rohtla, '14 aastat õpilaste ajalooalaste uurimistööde võistlusi' [14 years student historical research competitions], in Kakskümmend aastat Eesti Ajaloo- ja Ühiskonnaópetajate Seltsi [Twenty years of the Estonian Society of History and Civic teachers], Tallinn, 2014, p. 9.

${ }^{80} \mathrm{~S}$. Valdmaa, 'Ajaloo-olümpiaad uut moodi' [History Olympiad in a new way], Õpetajate Leht [Teachers' Newspaper], 24 October 1990, p. 7; A. Liim, 'Ajaloo olümpiaadidest ajaloopäevadeni’ [From History Olympiads to History Days], Kleio, no. 7, 1993, pp. 58-59.

${ }^{81}$ F. Kupp, 'Ikka pole veel uusi õpikuid' [Not yet new textbooks], Õpetajate Leht [Teachers' Newspaper], 3 November 1990, p. 6.

82 S. Valdmaa, 'Ajaloo-olümpiaad uut moodi' [History Olympiad in a new way], Õpetajate Leht [Teachers' Newspaper], 24 October 1990, p. 7.

83 'Haridusministeeriumi ja Eesti Ajalooõpetajate Seltsi koostööleping. HTM 10-10/940' [Cooperation agreement between the Ministry of Education and the Estonian History Teachers' Association. Ministry of Education and Science act no. 10-10/940], Tartu 20.09.2001, Archives of the History and Civic Teachers' Association.

${ }^{84}$ N. Klitsner, 'Kümme aastat ajalooklassi' [Ten years of specialised history classes], Haridus [Education], no. 3, 1996, pp. 52-53. 
Computer technology was used increasingly in history teaching. The first school computerization project was implemented in 1987-1992. From 1992-1996, IT resources were distributed to schools, and search and publication of suitable software for Estonian study programmes began as well as creation of original software. The Tiger Leap Program (1997-2000) was created in order to modernise the ICT infrastructure of schools. ${ }^{85}$ In 2002/2003, the online platform, Miksike, for tests was created. Teaching changed as a result: the teacher could choose course materials and, if necessary, process them. ${ }^{86}$ Learning became more and more creation of information, not just consumption of information. Students formulated their findings as a workbook or portfolio. However, a large part of the teaching staff needed samples and instructions to change the teaching-learning process. ${ }^{87}$

There was no general national study on the situation of history education. Conclusions could be drawn from the implementation of the syllabus, the use of study materials, and study activities obtained from history teacher questionnaires sent to schools in 2004. Teachers said there was not enough time for history and civics. More time was needed to develop thinking, analysis, and argumentation skills. Secondary school outcomes were achieved, especially analysis of mass media. Critical analysis of historical sources from various points of view and the development of empathy were mentioned as more difficult to achieve. Estonian history was easier for students to learn than general history. Teachers complained about the lack of access to the Internet to find additional learning materials. Not all history classrooms had the necessary computers and data-projectors. Use of computer classes took a long time to register. Among the respondents, the most popular method of teaching was the lecture, which the teachers considered effective. Independent work and discussion followed. Less use was made of project work, class trips, and research. In the survey section on goals of learning history, teachers considered critical thinking, analysis, and reflection to be the most important skills. The most influential factors for teaching was the interest of students, the history syllabus, and the national examination; to a lesser extent, textbooks were mentioned. ${ }^{88}$ Students mentioned the importance of learning history facts more often than

${ }^{85}$ Riiklike hariduspoliitikate ülevaated, Eesti [Review of national policies for education, Estonia], OECD, 2001, pp. 17, 24, 97-100.

${ }^{86}$ S. Tohver, 'Online kontrolltöö teeb õpetaja elu lihtsamaks' [Online test makes life easier for a teacher], Õpetajate Leht [Teachers' Newspaper], 31 May 2002, p. 5.

${ }^{87}$ From August to November 1987, teachers from general education schools, including history teachers, were surveyed to get an overview of the extra-curricular forms or additional material they had used. See S. Reinpalu, A. Ruubel, 'Õpetaja valmisolek avatud õppeks' [Teacher's readiness for open learning], Nõukogude Kool [Soviet School], no. 10, 1988, pp. 30-32.

${ }^{88}$ M. Oja, 'Mõnda ajalooõpetajate küsitlusest' [Some thoughts on history teachers survey], Õpetajate Lehe lisaleht [Teachers' Newspaper's Appendix], 18 February 2005, p. 9; 'Ajalooõpetajate küsitlus' [History teachers survey]. Available: http://www.ekk.edu.ee/vvfiles/0/ ajalooopetajate_kysimustik.pdf (accessed 23.02.2015). 
teachers. ${ }^{89}$ A second survey in 2004 showed that history was considered to be the seventh most popular subject among more than 15 subjects. ${ }^{90}$ Surveys showed that in ten years, the content of history teaching had changed more than teaching practices.

The Estonian History Teachers' Association, founded in 1993, had a great influence on history teaching. The same year, membership in the European History Teachers' Association EUROCLIO was also obtained. Independent initiatives were organised and the Society has been partnering with the Ministry of Education on various issues, including discussion about assessment, curriculum development, and textbooks analysis. The presence of Society members as experts in the Attestation Committee, subject councils, discussions of education policy gave teachers confidence that their opinions on the actual situation and their position were taken into account. Society membership provided teachers with a wider range of contacts with colleagues at home and abroad. Association activities supported the development of teachers and broadened their general and professional horizons.

\section{National Examination as an influence on history teaching}

The adoption of the first national curriculum was followed by completion of an external evaluation system. The first state exam in history took place in 1997. This was preceded by a nationwide test. ${ }^{91}$ The introduction of the exam accelerated the transition to study activities recommended in the 1996 National Curriculum - work with historical sources and maps and the development of discussion and analysis skills. State examinations in history took place annually until 2013.

The national examination in history was scored with 100 points - divided equally into 25 points each - for discussion, history of Estonia, general history, and the course 'Human-society-culture.' Tasks focused on curriculum learning outcomes and were skills-centred and of varying degrees of difficulty.

The examinations were prepared by a commission composed of recognised teachers (including from Russian-language schools) and university representatives. The tasks were discussed jointly and amended at various meetings, and test questions were answered by an independent expert (teacher and

${ }^{89}$ E. Tannberg, 'Õpilaste küsitlusest 2004. aasta ajaloo riigieksamil' [Students' survey on the history state exam in 2004], Õpetajate Lehe lisaleht [Teachers' Newspaper's Appendix], 18 February 2005, p. 9.

${ }^{90}$ L. Pallas, 'Kooli õpikeskkond ja õpilaste toimetulek. Ankeet õpilasele. Tabelid' [School as learning environment and students' coping. Student survey. Tables.], in E-S. Sarv, Õpetaja ja kool õpilase arengu toetajana. Õpetaja enesest ja koolist. CD Statistilised lisad [Teacher and school as supporters of student development. Teacher on her/himself and on school. CD Statistical appendix], Tallinn, Tallinna Ülikool, 2008, p. 49.

${ }^{91}$ M. Oja, 'Riigieksamid meil ja mujal' [State exams here and away], Haridus [Education], no. 11-12, 2006, p. 28. 
academic historian), edited, printed, and delivered to schools. An assessment guide was also prepared. The examination was anonymously assessed by the Commission. Since 2001, different parts of the test have been evaluated by different assessment teams. The essay was marked by two evaluators; evaluators could not see each others' comments and marks. The student received the average mark of both evaluators. Upon completion of the evaluation, the Commission convened to summarise, analyse student mistakes and responses, and make other observations, including unsuccessful wording of exam questions. Each year, substantive and statistical analyses of the exam were compiled and published. Those who were not satisfied with their grade could appeal the results. ${ }^{92}$ The Board of Appeal evaluated the work as a whole and changed the mark if warranted.

The results of the exams provided important information about student achievements. Every year, work with maps and sources and reflection skills improved. Yet, students displayed superficial knowledge of history, making mistakes because of superficial reading of the question, poor understanding of instructions, and struggles with the wording of the answers. Responses were generally superficial, emotional, and unsubstantiated. It was felt that the level of general literacy had declined. ${ }^{93}$ Statistics were poorly understood, and propaganda was not distinguished from scientific facts. The past was better known than recent history, and there was a stereotypical attitude towards the Soviet era. ${ }^{94}$

State exams drew immediate public attention. The development of learning skills was positive, but the ranking of schools by the media was negative. Objective feedback from exam results provided information on achievement of learning outcomes and the quality of education. Teacher pedagogical skills have

92 L. Reimann, 'Riigieksami tulemusi võib apellatsiooni korras vaidlustada' [The results of a state exam can be challenged by appeal], Õpetajate Leht [Teachers' Newspaper], 6 June 1997, p. 1.

93 A. Adamson, Ajaloo riigieksami analüüs 2007 [Analysis of history state exam 2007], 2007. Available: http://vana.ekk.edu.ee/statistika/analyys/23_AjaluguG.pdf (accessed 19.03.2015); R. Tõnnis, Ajaloo riigieksam 2012. Tulemuste analüüs [History state exam 2012. Analysis of results], 2013. Available: http://www.innove.ee/UserFiles/Riigieksamid/2013/Ajaloo\%20 re\%20lyhianalyys\%202012.pdf (accessed 10.03.2015); M. Oja, M. Räis, E. Tannberg, Ajalugu. Riigieksam 2002. Riigieksam 2003 [History. State exam 2002. State exam 2003], Tallinn, 2002, p. 56; E. Tannberg, 'Ajaloo riigieksam mullu ja tänavu' [History state exam last year and this year], Õpetajate Lehe lisaleht [Teachers' Newspaper's Appendix], 13 February 2004, p. 1; A. Adamson, Ajaloo riigieksami analüüs 2007 [Analysis of history state exam 2007], 2007. Available: http://vana.ekk.edu.ee/statistika/analyys/23_AjaluguG.pdf (accessed 19.03.2015).

94 A. Adamson, Ü. Kõiv, M. Oja, M. Räis, E. Värä, Eksaminandile ajaloo riigieksamist [About history state exam to student], Tallinn, Argo, 2002, pp. 43-56; M. Oja, M. Räis, E. Tannberg, Ajalugu. Riigieksam 2002. Riigieksam 2003 [History. State exam 2002. State exam 2003], Tallinn, 2002, p. 56; E. Tannberg, 'Ajaloo riigieksam mullu ja tänavu' [History state exam last year and this year], Õpetajate Lehe lisaleht [Teachers' Newspaper's Appendix], 13 February 2004, p. 1; A. Adamson, Ajaloo riigieksami analüüs 2007 [Analysis of history state exam 2007], 2007. Available: http://vana.ekk.edu.ee/statistika/analyys/23_AjaluguG.pdf (accessed 19.03.2015). 
been developed in the process of compilation and evaluation of examinations. ${ }^{95}$ In spite of the complexity of designing and evaluating skills of discussion and of thinking, the teachers considered the state exam to be most effective for changing teaching from fact-based knowledge towards skills development. ${ }^{96}$ Almost the same could be said about final exams in basic schools.

Students' achievements in history were tested at the end of grade 6 by a nationwide test first implemented in 2002. The suitability of the test itself was judged by members of the subject council, ${ }^{97}$ and results were assessed by history teachers. Each form of external evaluation provided feedback to state officials on the quality of education and subject teaching.

\section{Upgrading teaching literature}

Teachers were often guided by textbooks when planning the course rather than curriculum guidelines, so the textbook was very important in changing the learning process. Content, research methodology, assessment, and methodology were taken from textbooks, which made it possible to change teaching quickly and all over the country through textbooks.

Until new textbooks arrived in schools, articles from newspapers and magazines were mainly used to teach history. Historical literature was nonexistent or unavailable. The Teacher Newspaper had systematically published thematic articles that were not always up-to-date. ${ }^{98}$ Laine Levald, employee of the Ministry of Education, put together thematic lists of articles on historical issues from the press, which were sent to schools as a guide for teachers to facilitate finding suitable material.

History books from 1989-1994. During this period, the first textbooks corresponding to renewed history teaching concepts appeared. The first were Estonian history teaching materials. In total, 12 textbooks appeared - six Estonian history and six general history textbooks. The main innovation was replacing Soviet history with the development of an independent course in Estonian history.

The first textbook The History of Estonia was published by 18 authors in 1989: its purpose was to present historical facts missing from Soviet era textbooks. ${ }^{99}$

${ }^{95}$ M. Somelar, 'Riigieksamid - Eesti hariduse oluline väärtus' [State exams - important value of Estonian education], Õpetajate Leht [Teachers' Newspaper], 13 September 2013, p. 4.

${ }^{96}$ M. Oja, 'Muutused üldhariduskooli ajalooõpetuses alates 1987. aastast - nõukogulikust tänapäevaseks' [Changes in compulsory school history education since 1987 - from Soviet to present], PhD diss., Tallinn University, 2016, p. 326.

${ }_{97}$ 'Ajaloo ainenõukogu koosoleku protokoll 14.11.2003. Ainenõukogude protokollid 2001-2003' [The report of the meeting of the council of history 14.11.2003. Reports of subject councils 2001-2003], in Riiklik Eksami- ja Kvalifikatsioonikeskus sari [State Center for Examination and Qualification series], vol. 3-12, 2003.

${ }^{98} \mathrm{~K}$. Siilivask, 'Lisamaterjale Eesti ajaloo õpetamiseks keskkoolis' [Additional material for teaching Estonian history in high school], Õpetajate Leht [Teachers' Newspaper], 14 January1989, p. 3.

${ }^{99}$ S. Õispuu, 'Eesti ajaloo õppevahend keskkoolile' [Estonian history teaching tool for high school students], Õpetajate Leht [Teachers' Newspaper], 30 September 1989, p. 4. 
The book resembled a teacher's handbook and did not have a methodological component, maps, explanations of historical terms, or illustrations for students. It was the first textbook to include information about the Molotov-Ribbentrop Pact and call Red Army troops occupiers. However, World War II was still called the 'Great Patriotic War' ${ }^{100}$ in the Soviet tradition.

History textbooks from 1995-2001. The new textbooks passed testing in schools; teacher feedback was taken into account in subsequent editions. Publisher experience increased and technical facilities improved.

Part I of the textbook Humans, Society, Culture was published in 1998, part II in 2000, and part III in 2001. ${ }^{101}$ At the 15 September 1998 meeting of the National History Subject, the members of history decided to ask the Ministry of Education to temporarily suspend application of the curriculum in grade 11 until the textbook reached schools. ${ }^{102}$ The course 'Humans, Society, Culture' was developed and included in the 1996 National Curriculum: teachers could not rely on previous teaching materials.

During this period, 11 books were published, two of which were in Estonian history, and seven in general history as well atlases for basic schools ${ }^{103}$ and gymnasiums. ${ }^{104}$ Each of the schools was given an atlas of historical maps. ${ }^{105}$ The use of maps was essential as regional maps in textbooks could not replace world maps.

History books from 2002-2004. Six textbooks were published, two of which were on Estonian history and four on general history. There were also four different supplementary materials printed, such as collections of tests and exams, contour maps, and workbooks. Textbooks and their corresponding workbooks formed a set of learning materials.

${ }^{100} \mathrm{~S}$. Õispuu (ed), Eesti ajalugu. II osa. 19. sajandi lõpust kuni tänapäevani [Estonian history. Part II. From the end of the $19^{\text {th }}$ century to the present], Tallinn, Valgus, 1989, pp. 3, 86-87, 89, $118,141$.

${ }^{101}$ M. Kõiv, A. Mäesalu, K. Piirimäe, M. Tänava, 'Inimene, ühiskond, kultuur. I. Vana-Idamaad, Vana-Kreeka ja Vana-Rooma' [Person, society, culture. I. Old East, Ancient Greece and Old Roman.], in H. Piirimäe (ed.), XI klassi ajalooõpik [ $9^{\text {th }}$ grade history textbook], Tallinn, Koolibri, 1998; T. Aleksejev, et al., 'Inimene, ühiskond, kultuur. II. Keskaeg ja varauusaeg' [Person, society, culture. II. The Middle Ages and the early modern period], in H. Piirimäe (ed.), XI klassi ajalooõpik $\left[11^{\text {th }}\right.$ grade history textbook], Tallinn, Koolibri, 2000; K. Hiiemaa, O.-M. Klaassen, H. Piirimäe, K. Piirimäe, T. Tannberg, 'Inimene, ühiskond, kultuur. III. Uusaeg' [Person, society, culture. III. The modern period], in H. Piirimäe (ed.), XII klassi ajalooõpik [12 ${ }^{\text {th }}$ grade history textbook], Tallinn, Koolibri, 2001.

${ }^{102}$ I. Piir, 'Eesti Ajalooõpetajate Selts pidas aastakoosoleku' [The Estonian History Teachers' Association held its annual meeting], Õpetajate Leht [Teachers' Newspaper], 2 October 1998, p. 12; I. Piir, 'Ajaloo ainenõukogus' [In the Estonian History Subject Council], Õpetajate Leht [Teachers' Newspaper], 30 October 1998, p. 13; 'Ajaloo ainenõukogu pöördumine, Ainenõukogude protokollid 1997-2001, 23.09.1998, 22.11.1999' [History Subject Council's appeal. Protocols of Subject Councils 1997-2001, 23.09.1998, 22.11.1999], National State Center for Examination and Qualification, vol. 3-12.

${ }^{103}$ Ajaloo atlas põhikoolile [History Atlas for Basic School], Tartu, Tallinn, Regio, 2000.

${ }^{104}$ Ajaloo atlas gümnaasiumile [History Atlas for Secondary School], Tartu, Tallinn, Regio, 2000.

${ }^{105} \mathrm{H}$. Kinder, W. Hilgemann, Maailma ajalugu esiajast tänapäevani [World history from early days to today], Tallinn, Avita, 2001. 
A special edition of the journal Past ${ }^{106}$ was published about EstonianRussian relations, as well as other materials supporting Russian-language schools. Minutes of the Subject Council meeting indicate that assessment of new literature was the reason for frequent meetings from 2000-2004. ${ }^{107}$ Publication of textbooks was delayed, because the publisher did not get the manuscripts on time. Teachers had to manage on their own or use previously published textbooks.

To sum up, teaching materials became more diverse. Methodologically, textbooks became more meaningful. Textbook language was more age appropriate, the number of facts was reduced, illustrations were critically selected and more consistent with the text, and questions at the end of the chapter were more focused on learning outcomes that supported development of thinking skills. The authors were mainly academic scholars, and teachers created workbooks and additional study materials.

\section{History teaching materials in Russian-language schools}

The publishers did not get Russian translations of Estonian textbooks quickly. Thus, after the implementation of the 1996 National Curriculum, Russian-language schools received permission to use textbooks published in Russia: they accounted for 35\% of all textbooks used in the second half of the 1990s. ${ }^{108}$ Most textbooks were compiled in Estonian and translated into Russian. The text was not changed, but the translators attempted to make it more neutral when describing some events. Two textbooks - Estonian David Vseviov's History (1999) and Russian Andrei Fyodorov's 20 th century history Part I and Part II (2001-2002) - were first published in Russian and then translated into Estonian. ${ }^{109}$ Both were based on the Estonian National Curriculum. The authors competed and were selected by the publisher. Fjodorov's textbook was well received in Russian-language schools. The publisher believed that Russianlanguage school teachers and pupils had greater trust in a Russian author about information that previously had been banned. ${ }^{110}$ Lauri Vahtre's textbook

${ }^{106}$ The journal 'Tuna' [Past] has been published since 1998 by the National Archives with the support of Estonian Cultural Endowment and in co-operation with Tallinn City Archives and the Association of Estonian Archivists.

${ }^{107}$ I. Piir, 'Ajaloo ainenõukogus' [In the Estonian History Subject Council], Õpetajate Leht [Teachers' Newspaper], 12 May 2000, p. 10.

${ }^{108}$ N. Lapikova, 'Venekeelsest haridusest Eestis' [On the education in Russian-language in Estonia], Haridus [Education], no. 2, 1998, p. 8.

${ }^{109}$ D. Vseviov, Vzgljad v prošloje. Učebnik istorii dlja 5. klassa [View into past. History textbook for grade $5^{\text {th }}$, Tallinn, 1999; A. Fedorov, Istorija XX veka. Učebnik dlja gimnazij [20 $0^{\text {th }}$ century history. Textbook for high school], Tallinn, 2001-2002.

110 'Kirjastuse Avita toimetaja Arvis Kiristaja vastus Marko Mihkelsoni retsensioonile Andrei Fjodorovi õpiku käsikirjale Lähiajalugu' [Publisher House 'Avita' editor's Arvis Kiristaja's answer Marko Mihkelson's review of the textbook manuscript Recent history by Andrei Fyodorov], in Ainenõukogude protokollid 2001-2003 [Records of subject councils 2001-2003], vol. 3-12, State Center for Examination and Qualification. 
on Estonian history (2004) $)^{111}$ was specially designed for Russian-language schools for teaching history in Estonian. At the request of the Integration Foundation, a collection of historical sources, Turning Points in Estonian History (2008), was compiled for free distribution with additional materials for teachers and focused on Russia and Russians in Estonia. ${ }^{112}$ It supplemented the comprehensive textbook and provided opportunities for in-depth study of topics. Various, often conflicting, views in the textbook allowed students and teachers to analyse and understand the circumstances surrounding the creation of various sources and to reveal manipulation of history. Teachers in Russian schools criticised the fragmentary treatment of Russian history and the former communist republics in textbooks translated from Estonian into Russian: they claimed the books did not provide a comprehensive worldview and conveyed a Eurocentric perspective on the interpretation of history. ${ }^{113}$ The opposition claimed that the history textbooks were intended for Estonia's schools, regardless of the language of instruction. The volume of the textbooks was justified by the situation - students needed knowledge and differing views of Estonian and world history and to compare Soviet textbooks in which ideology and falsifications dominated. ${ }^{114}$ According to some, Estonian history needed to show Estonia's deep roots in Western culture and that the Russians who came to Estonia entered a completely different world. ${ }^{115}$

\section{Conclusion}

Changes in history and education as a whole began after the Teachers' Congress in 1987. The abandonment of Soviet-era traditions and ideology was revolutionary. Teachers had to refresh their knowledge and to rethink their perceptions about history. The central task was to formulate focus and objectives of history teaching and balance historical knowledge with skills, values, and attitudes in the learning process. First, the 'blank pages' of Estonian history were restored. The history of independent Estonia (1918-1940) had previously been taught from a deeply ideologised perspective and several topics were not discussed such as the treaty between Estonia and Soviet Russia, which was the first de jure recognition of the young, independent Estonian state. Tragic historical events - the deportations and occupations - could

${ }^{111}$ L. Vahtre, Eesti ajalugu gümnaasiumile [Estonian history for high school], Tallinn, 2004.

${ }^{112}$ T. Karjahärm, A. Adamson (eds.), Eesti ajaloo pöördepunktid. Dokumente ja materjale vene óppekeelega gümnaasiumile [Turning points in Estonian history. Documents and materials for Russian-language upper secondary schools], Tallinn, 2008; Eesti ajaloo pöördepunktid. Lisamaterjale õpetajale [Turning points in Estonian history. Additional material for the teacher], Tallinn, 2008.

${ }^{113}$ R. Grigorjan, 'Ajalugu koolis ja Eesti hariduspoliitika' [History in school and Estonian educational policy], Ốpetajate Leht [Teachers' Newspaper], 9 February 1996.

${ }^{114}$ P. Leppik, 'Võltsingut ja ajalugu ei sobi võrrelda' [Counterfeiting and history are not suitable for comparison], Õpetajate Leht [Teachers' Newspaper], 16 February 1996.

${ }^{115} \mathrm{~S}$. Tohver, 'Kodanikuõpetuse kaudu multikultuurilisse ühiskonda' [Via Civic education to/into a multicultural society], Õpetajate Leht [Teachers' Newspaper], 14 May 1999. 
not be discussed. Initially, primary attention was development of the content of the history. The syllabus achieved several principles that are still relevant today such as the development of critical thinking skills. The 1996 Curriculum gave teachers a high degree of decision-making power and, simultaneously, the responsibility to interpret the curriculum. Teachers were not prepared for their intended choices and increased responsibilities. The 2002 Curriculum did not bring about major changes but gave teachers stability.

The curriculum gave a frame and direction, but the key issue for educational change was the teaching staff. Educational practices needed to be transformed, educational materials developed, and innovative technology and new teaching approaches implemented. The activities of the History Teachers' Association were based on teachers' professional needs, which increased the confidence of teachers. Membership of EUROCLIO provided an opportunity to participate in international debates on history education.

In conclusion, from 1987 to 2004, history teaching in Estonian schools evolved from a Soviet ideological and biased subject into modern history teaching in terms of subject matter, student development, and methodology. The whole paradigm of history teaching changed. 